\title{
Some Important Facts about the Periodontal Disease
}

\author{
Ambarkova Vesna, PhD, MSc, DDS*
}

Department for Preventive and Pediatric Dentistry, University Ss.Cyril \& Methodius, Republic of Macedonia

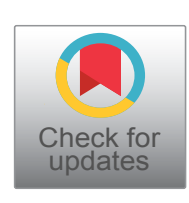

*Corresponding author: Dr. Vesna Ambarkova, PhD, MSc, DDS, Department for Preventive and Pediatric Dentistry, University Ss.Cyril \& Methodius, Skopje 1000, Republic of Macedonia, Tel: +38970686333

The periodontal disease is the most common chronic inflammatory disease of microbial origin, which acts on the supporting tooth tissues, including the periodontal ligament and alveolar bone. The most common form of periodontal disease is the mild form of gingivitis, which is the precursor of periodontitis as the most severe disease in this group and is defined as the apical extension of gingival inflammation, affecting parodontium. The parodontium is a specialized connective tissue that surrounds the root of the tooth and has a role in fixing the tooth for the jaw bone, in the amortization of the mechanical pressure that occurs in chewing and speech, but also in the formation and resorption of bone tissue. Its composition includes gingiva and periodontal ligament, such as soft tissue and alveolar bone and cement (enamel) as solid tissue [1].

The periodontal disease is initiated and aggregated by Gram-negative, anaerobic or micro-aerophilic bacteria that colonize the sub-gingival sulcus. The bacteria initiate the immune response of the host and destroy the tissues that provide the support of the tooth which leads to apical migration of the gingival tissues, loss of periodontal attachment, and an increase in the depth of the periodontal pocket. The most exposed to the action of plaque microbes is the connection between the gingiva and the tooth, that is, the outer gingival epithelium that communicates with the bone tissue of the jaw through the periodontal ligament [2]. By forming periodontal pockets, conversion of the joint epithelium into the pocket epithelium occurs and culminates with the loss of teeth.

There is a theory that periodontal disease is a pathological manifestation of the host's immune response directed against the bacterial challenge of sub-gingival biofilm. The degree of tissue damage depends on the interaction between host defense mechanisms and biofilm. The host response is mainly determined by genetic factors, the environment, systemic diseases such as diabetes mellitus, rheumatic diseases and acquired factors, such as smoking, and emotional stress $[3,4]$.

Also, periodontal disease, as a chronic reservoir of bacteria and endotoxins, aggravating cytokines and systemic inflammatory mediators, leads to endothelial damage, initiation and exacerbation of atherosclerosis and thrombogenesis, and thus acts on certain systemic diseases $[5,6]$.

In the 2010 US report, 64.7 million people over the age of 30 have periodontitis [7]. In the world, 15$20 \%$ of people aged between 35 and 44 have a severe periodontal disease pattern [8].

\section{Risk Factors}

Predisposing factors for periodontal disease include: Inappropriate oral hygiene and elderly, hormonal changes-with worsening of the disease activity during puberty, menstruation and pregnancy, diabetes mellitus, various genetic disorders that impair the function of neutrophils and rheumatoid arthritis [9-11]. An effective mechanism of host defense is highly vascularized gingival tissue, an oxidative barrier to penetrate anaerobic bacteria from the dental plaque. Conditions such as smoking and stress modify this barrier causing vasoconstriction of the peripheral arterioles and reduce the blood flow to the gingival tissue [3]. This provides enough time to survive the anaerobes in the tissues and cause an immune response by activating latent collagenase.

Smoking- The relationship between smoking 
and periodontal health has been explored since the middle of the last century. More recently, a wealth of epidemiological, clinical and in vitro studies have shown irrefutable evidence that smoking negatively affects periodontal health [12-15]. In vitro studies have shown a change in gingival cervical fluid with an inflammatory cytokine profile, an increased immune function and an altered proteolytic activity in smokers $[16,17]$.

Diabetes mellitus-Studies have shown an association between poor glycemia control and periodontal disease [18-20]. Taylor, et al. suggest a two-way link between periodontal disease and glycemic control $[4,21]$.

Psychological mellitus- Studies have shown that people with psychological stress are more likely to develop periodontal disease. A possible link in this chain may be the increased production of IL- 6 in response to increased psychological stress [22]. Another study suggests that the host's immune response to $P$. gingivalis infection can be compromised in people who are under psychological stress [23].

Genetic factors- Although bacterial infection is an aetiological agent in periodontal disease, studies of identical twins showed a $50 \%$ susceptibility to periodontal disease in the second twin [24].

Immune host response- There is an opinion that the occurrence and development of periodontal disease is the result of a hyper-immune response to bacterial infection, rather than a direct destructive effect of the bacterial pathogens themselves [25]. Polymorphisms of the IL-1 gene are associated with periodontal disease [25]. In addition, the evidence suggests the possible interactions between the IL-1 gene polymorphism with smoking and diabetes mellitus, indicating that there is an interaction between genetic and environmental factors, resulting in periodontal disease [26-28].

Deficiency in neutrophil function is associated with periodontal disease [29]. These are the chediak-higashi syndrome [30], cyclic neutropenia [31], lazy leukocyte syndrome, agranulocytosis, and leukocyte adhesion deficiency [32], Down's syndrome [33] and Papillon lefevre syndrome [34].

Aging is associated with an increased incidence of periodontal disease [35]. However, the increase in periodontal disease observed with aging is the result of cumulative destruction, so aging is not a risk factor in itself.

\section{References}

1. Maeda H, Wada N, Fuji S, Tomokiyo A, Akamine A (2011) Periodontal ligament stem cell. In: Gholamrezanezhad A, Stem cells in clinical and research. 619-636.

2. Cawson RA, Odell EW (2000) Essentials of oral pathology and oral medicine. ( $6^{\text {th }}$ edn), Churchill Livingstone, Edinburgh.

3. Hujoel PP, Drangsholt M, Spiekerman C, Derouen TA
(2002) Periodontitis-systemic disease associations in the presence of smoking-causal or coincidental? Periodontol 2000 30: 51-60.

4. Taylor GW (2001) Bidirectional interrelationships between diabetes and periodontal disease: An epidemiologic perspective. Ann Periodontol 6: 99-112.

5. Temelli B, Yetkin Ay Z, Savaş HB, Aksoy F, Kumbul Doğuç $D$, et al. (2018) Circulation levels of acute phase proteins pentraxin 3 and serum amyloid $A$ in atherosclerosis have correlations with periodontal inflamed surface area. J Appl Oral Sci 26: e20170322.

6. Saffi MAL, Rabelo-Silva ER, Polanczyk CA, Furtado MV, Montenegro MM, et al. (2018) Periodontal therapy and endothelial function in coronary artery disease: A randomized controlled trial. Oral Dis 24: 1349-1357.

7. Eke PI, Dye BA, Wei L, Thornton-Evans GO, Genco RJ (2012) Prevalence of periodontitis in adults in the United States: 2009 and 2010. J Dent Res 91: 914-920.

8. www.who.int/mediacentre/factsheets/fs318/en/

9. Ricci M, Garoia F, Tabarroni C, Marchisio O, Barone A, et al. (2011) Association between genetic risk score and periodontitis onset and progression: A pilot study. Arch Oral Biol 56: 1499-1505.

10. Stashenko P, Van Dyke T, Tully P, Kent R, Sonis S, et al. (2011) Inflammation and genetic risk indicators for early periodontitis in adults. J Periodontol 82: 588-596.

11. Recep Orbak, Sera Simsek, Zerrin Orbak, Fahri Kavrut, Meltem Colak (2008) The influence of type- 1 diabetes mellitus on dentition and oral health in children and adolescents. Yonsei Med J 49: 357-365.

12. Albandar JM (2002) Global risk factors and risk indicators for periodontal diseases. Periodontol 2000 29: 177-206.

13. Mokeem SA, Alasqah MN, Michelogiannakis D, Al-Kheraif AA, Romanos GE, et al. (2018) Clinical and radiographic periodontal status and whole salivary cotinine, IL-1 $\beta$ and IL-6 levels in cigarette- and waterpipe-smokers and E-cig users. Environ Toxicol Pharmacol 61: 38-43.

14. Bergstrom J (2014) Smoking rate and periodontal disease prevalence: 40-year trends in Sweden 1970-2010. J Clin Periodontol 41: 952-957.

15. Johannsen A, Susin C, Gustafsson A (2014) Smoking and inflammation: Evidence for a synergistic role in chronic disease. Periodontol 2000 64: 111-126.

16. Ryder MI, Fujitaki R, Johnson G, Hyun W (1998) Alterations of neutrophil oxidative burst by in vitro smoke exposure: Implications for oral and systemic disease. Ann Periodontol 3: 76-87.

17. Mark I Ryder, Ron Fujitaki, Scott Lebus, Mahyar Mahboub, Brandi Faia, et al. (1998) Alterations of neutrophil L-selection and CD 18 expression by tobacco smoke: Implications for periodontal diseases. Journal of Periodontal Research 33: 359-368.

18. Guzman S, Karima M, Wang HY, Van Dyke TE (2003) Association between interleukin-1 genotype and periodontal disease in a diabetic population. J Periodontol 74: 11831190.

19. Tsai C, Hayes C, Taylor GW (2002) Glycemic control of type 2 diabetes and severe periodontal disease in the US adult population. Community Dent Oral Epidemiol 30: 182192.

20. Crincoli V, Ballini A, Fatone L, Di Bisceglie MB, Nardi GM, 
et al. (2016) Cytokine genotype distribution in patients with periodontal disease and rheumatoid arthritis or diabetes mellitus. J Biol Regul Homeost Agents 30: 863-866.

21. Nishimura F, Iwamoto $Y$, Mineshiba J, Shimizu A, Soga $Y$, et al. (2003) Periodontal disease and diabetes mellitus: The role of tumor necrosis factor- alpha in a 2-way relationship. J Periodontol 74: 97-102.

22. Kiccolt-Glaser JK, Preacher KJ, MacCallum RC, Arkinson C, Malarkey WB, et al. (2003) Chronic stress and agerelated increases in the proinflammatory cytokine II-6. Proc Natl Acad Sci USA 100: 9090-9095.

23. Houri-Haddad Y, Itzchaki O, Ben-Nathan D, Shapira $L$ (2003) The effect of chronic emotional stress on the humoral immune response to Porphyromonas gingivalis in mice. J Periodontal Res 38: 204-209.

24. Michalowicz BS, Diehl SR, Gunsolley JC, Sparks BS, Brooks CN, et al. (2000) Evidence of a substantial genetic basis for risk of adult periodontitis. J Periodontol 71: 16991707.

25. Van Dyke TE, Serhan CN (2003) Resolution of inflammation: A new paradigm for the pathogenesis of periodontal diseases. J Dent Res 82: 82-90.

26. Socransky SS, Haffajee AD, Smith C, Duff GW (2000) Microbiological parameters associated with IL-1 gene polymorphisms in periodontitis patients. J Clin Periodontol 27: 810-818.

27. Deppe H, Mücke T, Wagenpfeil S, Kesting M, Karl J, et al. (2015) Are selected IL-1 polymorphisms and selected subgingival microorganisms significantly associated to periodontitis in type 2 diabetes patients? a clinical study.
BMC Oral Health 15: 143

28. Sharma N, Joseph R, Arun R, Chandni R, Srinivas KL, et al. (2014) Cytokine gene polymorphism (interleukin-1 $\beta+3954$, Interleukin-6 [-597/-174] and tumor necrosis factor- $\alpha-308)$ in chronic periodontitis with and without type 2 diabetes mellitus. Indian J Dent Res 25: 375-380.

29. Hajishengallis E, Rashewsky S, Kulkarni C, Stathopoulou $P$ (2016) Autoimmune neutropenia as a cause of periodontal disease in preschool children. J Clin Pediatr Dent 40: 69-75.

30. Thumbigere Math V, Rebouças P, Giovani PA, PuppinRontani RM, Casarin R, et al. (2018) Periodontitis in chédiak-higashi syndrome: An altered immunoinflammatory response. JDR Clin Trans Res 3: 35-46.

31. Chen Y, Fang L, Yang X (2013) Cyclic neutropenia presenting as recurrent oral ulcers and periodontitis. $\mathrm{J}$ Clin Pediatr Dent 37: 307-308.

32. Hajishengallis G, Moutsopoulos NM (2016) Role of bacteria in leukocyte adhesion deficiency-associated periodontitis. Microb Pathog 94: 21-26.

33. Scalioni FAR, Carrada CF, Martins CC, Ribeiro RA, Paiva SM (2018) Periodontal disease in patients with down syndrome: A systematic review. J Am Dent Assoc 149: 628-639.

34. Roberts $\mathrm{H}$, White P, Dias I, McKaig S, Veeramachaneni $\mathrm{R}$, et al. (2016) Characterization of neutrophil function in papillon-lefèvre syndrome. J Leukoc Biol 100: 433-444.

35. Grossi SG, Genco RJ, Machtei EE, Ho AW, Koch G, et al. (1995) Assessment of risk for periodontal disease. II. Risk indicators for alveolar bone loss. J Periodontol 66: 23-29. 